\title{
Push Factors towards Consociational Democracy in Plural Sub- National Polities: The Case of Mandera County, Kenya
}

\author{
Joseph M. Mutungi* \\ Kenya \\ *Corresponding Author: Joseph M. Mutungi, Kenya

\begin{abstract}
Consociational democracy has been advanced as the antidote to politically motivated violent conflicts in plural societies because of its strong support for inclusion of all significant segments in the population. This variant of democracy is advanced as favoring peace and stability. The focus of research has however tended to be on heterogeneity at the national level. Little research exists to examine the pull factors towards consociational democracy at the sub-national polities, most of which exhibit heterogeneity within homogeneity, thanks to gerrymandering by the political elite during the review of boundaries. This study which is anchored on the social capital theory, argues that social-cultural networks at the sub-national level strongly influence support for consociational democracy which is organized along ethnic identities. Instructively, the primordial and instrumental identities are used simultaneously depending on what the concerned social group $(s)$ intend to achieve.
\end{abstract}

Keywords: Consociational, democracy, religion, equity, social capital, identity, clan, inclusion

\section{INTRODUCTION}

The international system continues to grapple with the challenge of violent conflicts occurring in different parts of the world. Conflicts vary in terms of their nature, duration, stage, and underlying causes. They essentially are an endemic phenomenon associated with an inevitable co-existence in all human societies. Conflicts in and of themselves are neither destructive nor constructive; their progression, suppression or resolution largely depends on how they are handled. The period prior, during and after the conflict provides opportunities that if maximized can restore relations between the parties to the conflict, hence consolidating peace in the long-term.

Consociational democracy as a form of negotiated democracy focusses on sharing of power between various segments that make up society (Lijphart, 2012). This form of democracy acknowledges that at the heart of democracy lies majority rule. However, its proponents hold the view that, a literal interpretation and execution of majority rule can sometimes lead to an exclusion of minorities who have a right to representation and decision making, particularly those decisions that affect their existence. Exclusion of segments whether minorities or significant groups from the political life of a society has the potential and indeed has led to violent conflicts.

The proponents of consociational democracy argue that it is particularly useful in plural societies, where cultural differences are significant and identities are accentuated (Lijphart, 2012; Cammett \& Malesky, 2012; Andeweg, 2000). The concept is advanced as an all-inclusive approach to democracy that seeks to incorporate as many actors in the political matrix as possible through the processes of compromise and accommodation of constituent segments' elite. The obtaining all-inclusive arrangement is projected as the antidote to politically motivated tensions and their attendant instability in the referent polity.

In Asia, the political union between Malaysia and Singapore was short-lived as the latter seceded from the former in 1965 after only two years due to escalating conflicts revolving around racial and ethnic inclusivity in the political landscape of the federation. Indeed, the reality of ethnic and racial diversity largely informed Malaysia's review of her constitution in order to accommodate that identity diversity in political representation and this set the country on the path of stability (Shamsuddin, Liaw \& Ridzuan, 2015). Moreover, policy instruments such as the National Economic Policy have also been negotiated and adopted in order to accommodate all groups in the social and economic life of 
Malaysia in an equitable manner. The Malaysian experience suggests that when properly implemented, consociational democracy coupled with other factors has the potential to transform a polity from instability to peace and stability.

In the African setting, identities that seek to foster differentiation are based on ethnicity or its aliases variously referred to as tribes, sub-tribes, or clans (Posner, 2007). Ethnic-based politics have been positively correlated with political violence and other forms of conflicts and instability in situations where there are political gains and losses at stake (Butale, 2015). This study espouses ethno-political conflicts as those disagreements between and among ethnic groups arising from political interests and or contests. The study presents ethno-political conflicts as intentional moves calculated to achieve certain desired goals by individual political elites who use their ethnic groups as bargaining chips to political power and influence.

The salience of identity difference, popularly referred to as ethnicity in African politics and conflicts is well documented (Cheeseman, 2015; Bratton \&Kimenyi, 2008). Cheeseman and Ford (2007) for instance argue that ethno-political fragmentations and geographical concentration of ethnic groups are important factors in explaining Africa's ethnic-based politics and its attendant upheavals. The duo paints a picture of a continent whose politics is typified by overreliance on ethnic support bases. This view is buttressed by the findings of a study conducted by Teshome-Bahiru (2008) in Ethiopia in which overwhelming evidence indicates that formation of the political parties is largely informed by ethnicity. It is important to note here that the primordial ties alluded to by Teshome-Bahiru are stronger in attracting followers to a political party rather than the ideological orientation or claims, if any at all, made by the party.

Against this background, political contests are thus reduced to a matter of ethnic or even clan mobilization against competitors. This argument is supported by African history that documents African societies as having been divided along ethnic lines and the ethnic groups as further subdivided into clans (Alesinaet al., 2011; Boone, 2003; Murdock, 1959). From the clan level, regional and national politics emerge as candidates are assured of near fanatical following by their kith and kin. The primordial approach to identity dominates political mobilization at the clan level of political organization but swiftly transits into the instrumentalist understanding of identity where a common culture brings together several clans to form the ethnic group. It is out of that kind of understanding that ethno-political conflicts become inevitable as political competition becomes a zero-sum game. Negotiated democracy and particularly the consociational model has thus come in handy to prevent, manage and/or resolve ethno-political conflicts.

In comparing Kenya to other African countries , Njoroge and Sperling (2017), assert that politics in Kenya is less about pertinent issues and ideals that touch on the lives of its citizens but more about ethnicity and tribalism. They advance with evidence the argument made by Cheeseman and Ford (2007) that the political realm of Kenya right from independence was established and continues to be fed by patrimonial ethnic-based politics which mostly end up in violent conflicts. The politics of ethnic identity and its attendant negative effects in Kenya became manifest in the 2007 general elections especially in the race for the presidency. The announcement of the presidential election results plunged the country into violent conflicts that claimed 1133 lives besides displacing hundreds of thousands of people (CIPEV, 2008). A power sharing agreement brokered by the African Union pulled the country out of the conflict and set it on the path to reform and recovery.

The practice of consociational democracy in Kenya post the 2008 period extended to the subnational level following the adoption of the Constitution of Kenya (CoK) 2010 that established the devolved system of governance being practiced in the 47 counties. Socio-political stability in Kenya is threatened by sharp divisions between diverse ethnic groups and in the case of sub-national units like Mandera County, the divisions take clans and sub-clans dimension. The consociational approach to democracy was for a long time practiced by the Kenyan Somali community albeit subtly. Its main promoters had been the elders within the clans. It however gained traction in the 2013 and 2017 general election cycles, particularly in Mandera County which forms the referent polity for this study. However, little is known about what motivated the residents of Mandera County to embrace it, particularly in the 2013 election cycle. This is what the study sought to establish, in anticipation that the findings would enrich Lijphart's theory by focussing on the clan level of analysis which is a key plank in the formation of the African ethnic group concept. 


\section{LITERATURE REVIEW}

This study was anchored on Putnam's (1995) social capital theory which he developed from the work of classical sociologists such as Durkheim and Marx. The theory perceives social relationships as resources that can be used to drive development in its many facets. Within the context of the pull factors towards consociational democracy, the study concurs with the theory's contention that the threat of losing social bonds is a powerful inhibitor of violent conflicts which leave death and destruction in their wake. In the referent community, both bridging and bonding forms of social capital (Woolcock, 1998) are manifest as identity takes both instrumental - the Somali identity and primordial - specific clan or sub clan dimensions.

Consociational democracy has been promoted as one of the most progressive approaches in the management of ethno-political conflicts in plural societies, with Lijphart (2012) describing it as 'gentler and kinder'. The concept recognizes the ambitions, insecurities and the legitimate concerns inherent in ethnic groups, thus offering an opportunity for peacefully managing ethno-political conflicts. The study notes that the choice of democracy adopted depends on an array of dynamics such as demographic composition and trends within a polity, the attendant level of political consciousness and resource availability.

Competitive politics are characterized by conflicts without which democracy loses its raison d'etre (Vasilev, 2015). The concept of conflict that Vasilev alludes to in his argument is not necessarily underpinned by violence but rather an expression of disagreements between the contending parties. The very nature of competitive politics in a typical laissez faire democracy is such that winners and losers are generated at the end of the process and hence conflicts will always be there at any point or throughout the electoral process.

Lijphart (2012) in his typologies of democracy takes the view that the focus of democracy is people's participation in their own governance; freedom of choice is to be exercised in a manner consistent with the realities in society and the intent to meet the needs of the societal membership. According to him, a consociational approach to political power sharing is crucial in ensuring the stability of polities hosting multiple culturally-diverse groups. The key feature of the consociational model that he champions in plural societies is the inclusion of important segmental actors in the political power matrix by bringing together the elites of the various segments. The elites are motivated with incentives that move them towards cooperation such as the promise of exercising power.

Lijphart seems to assume that elites have the political will to cooperate and will then drag along with them their respective constituents into the cooperation, hence stability in the polity. Whereas Lijphart prefers moderate elites, Horowitz (2002) argues that coalitions should incorporate people with extreme views so that they can contribute to transforming them. Though he does not give his reasons for the transformation, this study takes the view that transformation acknowledges the organic nature of society and the need for systems to evolve with it. In addition, the moderates in the spirit of reciprocity can help the extremists change or modify their behaviour.

In most divided societies, ethnic groups tend to owe their allegiance to the group rather than the state. In other words, the primordial identity is stronger than the instrumental identity particularly in matters that directly affect the existence of a community such as the practice of politics. Binningsbo (2005) argues that cooperation between ethnic groups in a polity is low due to trust issues. This study argues that cooperation and trust is higher within ethnic groups due to the strong bonds of social capital in such groupings. Moreover, some elements of identity such as religion are fixed and thus not subject to compromise. It is important to note that identity based conflicts must be analysed contextually because there can never be a solution that is applicable to all societies as Putnam (2000) alludes. In managing such types of conflicts, the choice of a management approach needs to be informed by the understanding that the particular style affects the structure of the conflict and the goal of containing the destructive component of the conflict must triumph.

The findings of a study carried out in the Democratic Republic of Congo (DRC) by Ngoy-Kangoy (2007), which focused on the 1960 and 2006 legislative and presidential elections established that formation of political parties and alliances in the country are to considerable degrees defined by linguistic, economic and regional factors. A critical analysis of this case of DRC reveals the significance the social identity theory whose fulcrum is the 'othering' mentality i.e. if they do not 
speak our language and share in our culture they can turn against us. Internal cohesion and unity of purpose among speakers of same language and practitioners of same culture is thus a solid ground for forming groups to pursue and protect common interests. This argument is in sync with Putnam's (2000) views that ethnic identities are not mere facts of categorizations but rather strong pedestals around which the interests of a group are built and articulated. When members of the group buy into the us-versus-them dichotomy, violence becomes a justifiable pathway in the pursuit of the group's interests. The study further demonstrates that ethnic identities remain the key political mobilizing element as groups seek to position themselves to benefit out of the sharing of resources. The shortcoming with NgoyKangoy's study however is that ethnicity is considered at the group level which this study refers to as the instrumental level and internal dynamics and differences among subgroups forming the larger group do not find any expression in his work. This is a glaring omission that ethnic based studies should seek to fill, without assuming subgroups are in harmonious relations under the umbrella of the bigger identity.

A review of Van Dyke and Amos' (2017) study on drivers of social movement coalition formation, longevity, and success identifies social ties, ideology, culture, identity, and resources as among the critical factors that influence formation of social and politically motivated movements. They further note that family ties also inspired group formation in seeking a political change to their plight. It is important to reiterate here that identity can be by circumstance, choice or coercion and it is essentially socially constructed as White (2010) argues. In other words, identity is not always primordial as implied by Lijphart (2012).

In a study conducted in Ghana on the nexus between elections and conflict management, Ayezaluno (2011) argues that elections in Ghana's majoritarian system are a zero-sum game in which elites use all means at their disposal to win. Although in the last decade Ghana has been presented as the poster child of democracy in Africa, the country has and continues to battle inter-ethnic and intra-ethnic political conflicts (Tonah, 2007). As is the case with many African countries, Ghana's political processes are grounded in identity differences, irrespective of whether the identity is primordial or instrumental/constructed. Identity differences in Ghana take different forms such as Northerners versus Southerners, Ewes versus the Akan, the former taking a constructed view of ethnicity and the latter a primordial one. Given the destabilizing effect of exclusion, politicians have been forced by these ethnicity dynamics among others to form alliances and coalitions for winning power and sharing the spoils that come with political power. Ayezaluno stresses the fact that toxic patron-client networks are very much in place in the case of Ghana as elsewhere, noting the dearth of rational voters. The study strongly argues that some primordial groups prioritize their sub-national citizenship or loyalty over the national one and this point to the levels of solidarity and the need for inclusion in political processes as a means to averting the use of violence in handling conflicts and thus enhancing stability. The kernel of the argument that the study makes is that all communities actively seek a representation in political and resource sharing decision making for them to assure themselves of their own existence.

\section{MeThOdologY}

The study adopted a descriptive research design that incorporates both qualitative and quantitative approaches, because of the design's capability to provide a picture of consociational democracy as happens in its natural setting (Creswell, 2014).In this design, quantitative methods were used to collect, analyze and represent relationships between variables mathematically through statistical analysis, with the primary tool for quantitative data generation being a questionnaire. The results were then interpreted in order to draw data-based conclusions. Qualitative methods were also used to understand and describe various phenomena in the research area as found in the data collected through in-depth interviews and Focus Group Discussions (FGDs).

The mix of methods in this design was preferred for this study because as Creswell (2014), explains, it provides room for a researcher to examine real-life contextual understandings and multi-level perspectives of phenomena. The mix also allowed the researcher to integrate the strengths of quantitative and qualitative approaches in order to formulate a holistic interpretive framework for generating possible solutions or new understandings of the problem (Creswell, 2008). The decision to use mixed methods in the descriptive research design was further informed by the reality that the variables and constructs that this study focused on form a complex web with forward and backward linkages. 
The study targeted elected politicians and former aspirants, religious, communal and special interest group leaders such as women and the youth as well as heads of households drawn from across the three major towns of Mandera, Rhamu and Elwak. Heads of organizations working in peace building and conflict management in Mandera County also formed part of the targeted population. A sample size of 372 was obtained from the target population using both probabilistic (stratified and simple random sampling) and non-probabilistic (purposive and snow ball) sampling methods. The quantitative data was analyzed using descriptive and inferential statistics while the qualitative data was thematically analyzed.

\section{FINDINGS AND DISCUSSION}

Closed and open-ended questions were developed to assist the researcher obtain data that would enable him establish the various pull factors that influence adoption of consociational democracy in the management of ethno-political conflicts in Mandera County. The findings are as presented and discussed in the following sections.

\subsection{Desire for a Political Process Free of Violence and Destruction}

The findings in relation to this statement are as presented in Figure 4.1. The results indicate that $69 \%$ of the respondents strongly agreed that the desire for a political process free of violence and destruction was a push factor for them to support consociational negotiated democracy in the management of ethno-political conflicts. A further $18 \%$ of the respondents agreed with the question statement while $6 \%$ were indifferent. $5 \%$ of the respondents disagreed with the statement while $2 \%$ expressed strong disagreement with it.

A response of $87 \%$ of the respondents indicating agreement with the statement suggests that historically, political activities in the county and among the clans have been beset with violence. The findings could also mean that the competitive clan-based organization of politics in the county has been fueling animosity among the residents, an outcome that most of them would wish to see reversed. The results may also be indicative of personal experiences with the adverse effects of a violent political process such as the loss of a loved one or even the destruction of property that was their lifeline and which the respondents would never wish to encounter again.

Political processes in democracies, which Kenya (and all sub-national polities within her) unequivocally states she is, are intended to be violence free because it undermines stability. However, the dominant majoritarian system in many democracies has been reduced to zero-sum contests that produce winners and losers, an outcome that creates instability in the concerned polity, even though such instability is not necessarily manifested in violence. The study concurs with Söderberg and Bjarnesen(2018) that the propensity for violence in majoritarian systems is particularly high where there is no established culture of accepting electoral outcomes or the processes are prone to manipulation. It therefore follows that the electorate in areas prone to politically motivated violence such as Mandera County would be more willing to support an approach that promotes mechanisms that curtail instability such as consociationalism. From its inception, respondents seemed to believe that management of ethno-political conflicts through consociational democracy could mark the end of animosity which exists between the different clans.

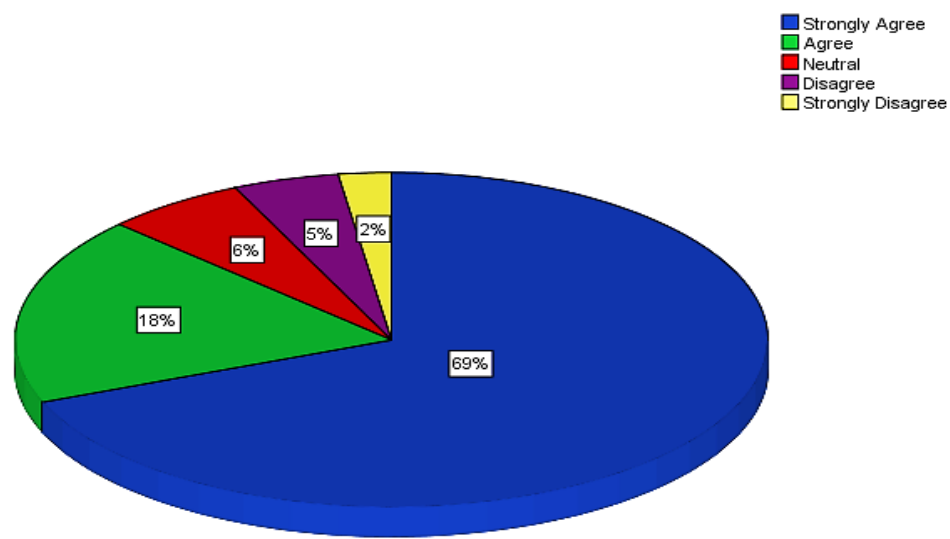

Figure4.1: Desire for violence and destruction free political process

Source: Study Findings, 2019 


\subsection{Fairness in Sharing of Political Positions}

The study findings in Figure 4.2 indicate that $55 \%$ of the respondents in this study agreed that fair sharing of political positions in the county was a push factor for them in their decision to support the adoption of consociational democracy in the county following the roll out of the devolved system of governance.This means that slightly more than half of the respondents thought that consociational democracy would deliver fairness in the sharing of political positions. On the other hand, a significant proportion of the respondents, $37 \%$ disagreed with the statement while $8 \%$ were indifferent.

From these findings, majority of the respondents do not think that the system used prior to adoption of consociational democracy was fair in the manner in which political positions were shared among the clans in the county. The results also seem to suggest that there were attempts by the champions of consociationalism aimed at explaining the benefits of the approach, particularly its potential in ensuring equity in political power sharing. The fairly significant findings expressing disagreement with the statement point to the respondents' skepticism with the potential of consociationalism to help manage ethno-political conflicts in a county where some clans may have dominated the political landscape. The assurance of political positions, though significant for the community, may not mean much to an individual who is apolitical and would rather support a system that brings stability for him to pursue his interests.

In any political unit where power is contested by several actors, there is a tendency among groups that have been or perceive themselves to be victims of systemic exclusion to support an alternative arrangement that accommodates them. The concept of proportionality as theorized by the scholars of consociationalism is particularly tempting for small groups and if implemented faithfully, it can usher in stability. This has been proven in the case of Malaysia where accommodation of all significant segments set the country on a path to stability as argued by Henry (2016). The over one third dissenting views may be construed to mean that politics in African societies are characterized by deceit and uncertainty. This finding also suggests that a fraction of the electorate is not so keen on the disparities in society and may have resigned to fate: all they prefer is a stable and peaceful environment which is what consociational democracy promises.

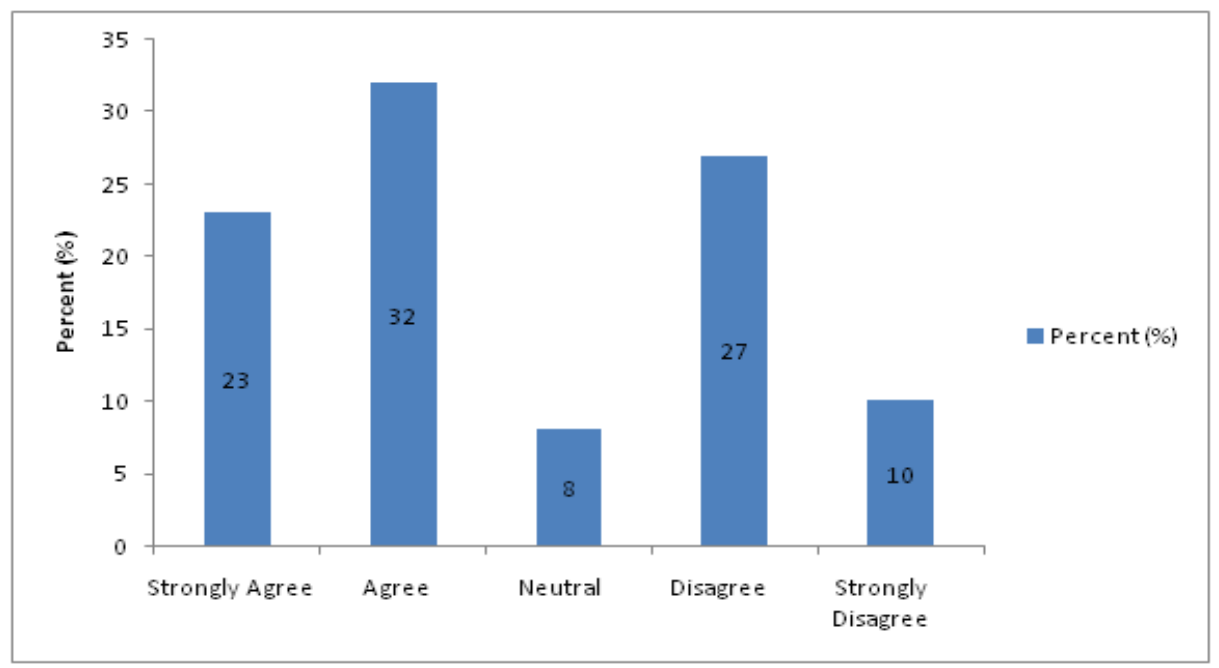

Figure4.2: Assurance of fairness in sharing political positions

Source: Field data, 2019

\subsection{Fair Distribution of Economic Resources}

Figure 4.3 indicates that $74 \%$ of the study participants agreed that the promise of fair distribution of economic resources influenced adoption of consociational democracy as a strategy for managing politically instigated inter-ethnic conflicts in Mandera County. About 17\% of the respondents disagreed while $9 \%$ expressed neutrality with regard to the statement.

The study findings are emphatic that the pre-consociational democracy period was characterized by inequalities in the distribution of resources accruing to the polity, a factor that may have been contributing to the recurrent politically motivated conflicts among clans. Economic resources are the 
backbone of a society's existence and any threat to such resources provides fodder for violence from those that are threatened. Resource based conflicts that are manifested in political processes have been witnessed in many African countries such as the Democratic Republic of Congo, where ethnic groups wrestle for power as a platform to control the resources (Burnley, 2011). The study argues that a political system that promises groups an opportunity to be in power and consequently get their fair share of resources will tend to gain overwhelming support, more so if that polity has experienced recurrent conflicts and periods of marginalization as is the case with Mandera County.
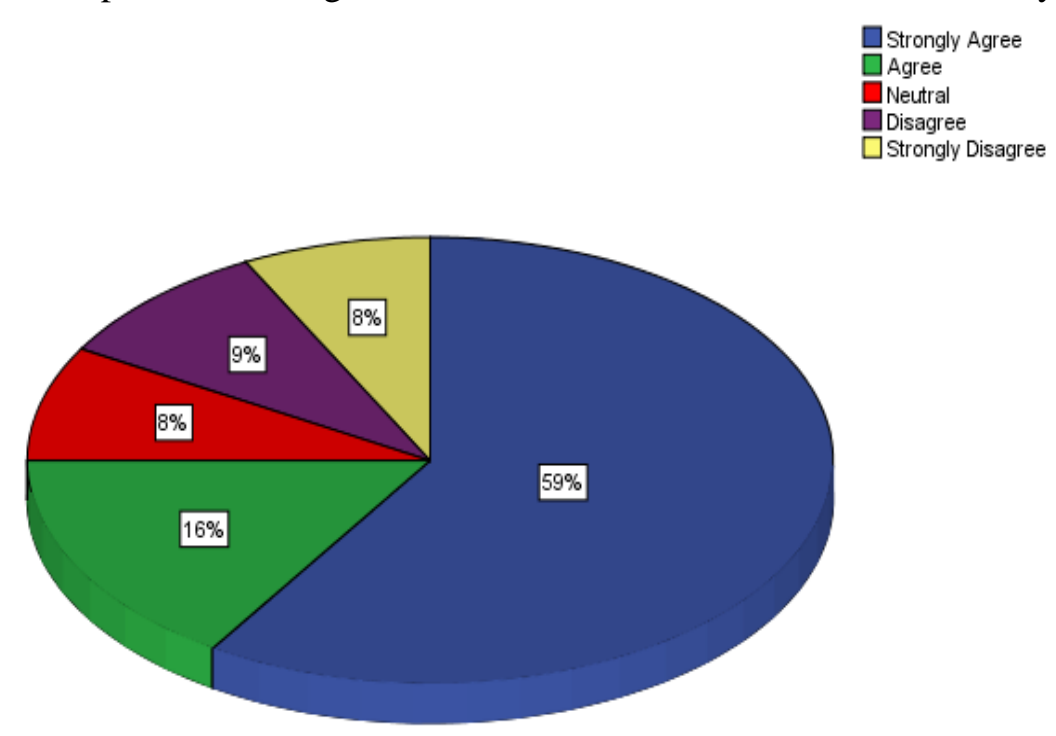

Figure4.3: Promise of fair distribution of economic resources

Source: Study Findings, 2019

\subsection{Religious Teachings}

As demonstrated in Figure 4.4, 67\% of the respondents expressed strong concurrence with the statement that religious teachings on peaceful dispute resolution influenced adoption of consociationalism, a view shared by a further $17 \%$ of them. However, about $9 \%$ of the respondents disagreed that religious teachings had any role in the adoption of consociational negotiated democracy in the county. The remaining $8 \%$ of the respondents were not certain on whether or not this element was a motivator for the adoption of consociationalism as a way of resolving the politically inspired inter-ethnic conflicts in the county.

As anticipated, the findings imply that religious teachings, specifically those of Islam which is the predominant religion in the county as indicated by $98 \%$ of the respondents, significantly influenced adoption of consociational democracy. This is because the religion, just like other religions, emphasizes values such as equality, fairness and peaceful resolution of disputes which is what most residents desired. The finding could also be suggestive of the extent to which Islamic religious teachings have been integrated in the political as well as the dispute resolution mechanisms of the dominant ethnic Somali community in Mandera County. The findings may also mean that the grassroot network of religious institutions and their leadership may have been promoting consociational democracy as a pathway to the political accommodation of all clans and peace among the populace while making reference to the teachings of the Quran.

Religious teachings and contextually those of Islam as contained in the Holy Quran and the Hadith series emphasize peace. The finding on religious influence in the adoption of the consociational democracy is in sync with Abu-Nimer's (2010) assertion referencing the Quran that the Islamic faith forbids violent behaviour while encouraging peaceful coexistence among all people who are equal before God. His position is further supported by Kadayifci-Orellana (2010) who argues that it is the duty of every Muslim to uphold peace. Thus, the study findings are in perfect harmony with the extant literature on the pursuit of innovative approaches to dispute resolution that deliver peace dividends. Religion is part of a society's culture and this study argues that it primordially strengthens social bonds among members of a community or instrumentally bridges those bonds to the extent that there is a willingness to let other differences be subservient to it. 


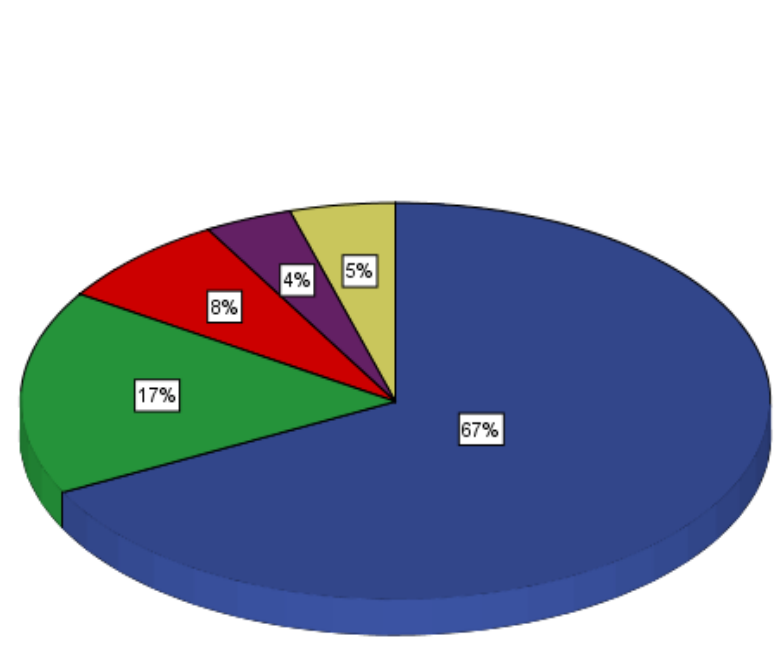

Source: Field data, 2019

Figure4.4: Influence of religious teachings

\subsection{Cross-Cutting Family Ties}

Respondents were asked their views on the influence of family ties on adoption of consociational democracy and the findings are as per Table 4.1.From Table 4.1, 66\% of the respondents agreed that cross-cutting family ties influenced adoption of consociational democracy in the county as a means to addressing ethno-political conflicts. Approximately $10 \%$ of the respondents expressed neutrality with regard to this statement while $24 \%$ of the respondents disagreed that family ties influenced adoption of consociational democracy in the county.

The findings suggest that family ties transcend the boundaries of clannism in the sense that cross-clan marriages have occurred in Mandera County. There is increased mobility of people as they pursue different interests such as education or economic opportunities and such mobility can require an individual to be away from the geographical concentration of their clan. Moreover, marriage and love are matters that are personal and in the pursuit of such private undertakings, clan affiliation may be relegated to a lower level compared to personal choice. As such, marriage connects families and consequently clans. The end result, as the study finding suggest would be the thawing of inter-clan relations and the possibility of erstwhile rivals working together.

Inter-clan marriages are a common cultural practice that is highly encouraged among the clans as they are believed to foster the unity of the clans involved (Tadesse, 2010). Such marriages are used as a social measure to encourage peaceful coexistence among the clans constituting a community. The study argues that people who consider each other as family on account of marriage, clan differences notwithstanding are less likely to attack each other in the event of disagreements and would rather adopt dialogue. In essence, family ties encourage cooperation and sharing rather than competition and exclusion.

\subsection{Insufficient Campaign Finances}

The statement sought to establish whether insufficient campaign finances within clans had any role in the adoption of consociational democracy and the findings are illustrated in Figure 4.5.Over 70\% of the respondents expressed their agreement that insufficient campaign finances influenced the decision by clans to adopt consociational negotiated democracy in Mandera County. That $56 \%$ of this group of respondents strongly agreed with the statement demonstrates the salience of finances in political processes in the county. Approximately $20 \%$ of the study participants disagreed with the statement. The remaining $6 \%$ of the respondents were neutral on the influence of finances in the adoption of consociationalism in Mandera County.

The findings were interpreted to mean that political campaigns are an expensive affair that can drain individuals and groups financially. They also suggest that the majoritarian system which existed prior to the mooting of consociationalism was a preserve of those that could assemble a formidable war chest to mount the campaigns. It can also be deduced that small clans that could not pool the resources needed for campaigns had no chance of ascending to political office as they had no capacity to 
campaign against their more financially endowed rivals and this served to exacerbate rivalry among dominant clans and the smaller ones.

Campaign financing is a major issue in democracies because it can influence the direction an election will go, especially in societies where politics is not organized along ideologies such as Kenya (Kanyinga, 2014). The study concurs with the findings of Posada-Carbo (2008) that uncontrolled injection of financial resources can undermine the legitimacy of not just candidates or political parties, but also the political process itself. A consociational model on the other hand is not as expensive because the agreements ensure inclusion of those who may not have sufficient campaign funds as their place in the political matrix is predetermined. Thus smaller clans operating from the premise of realpolitik would rather support a system that favors them to achieve their ends of political participation.

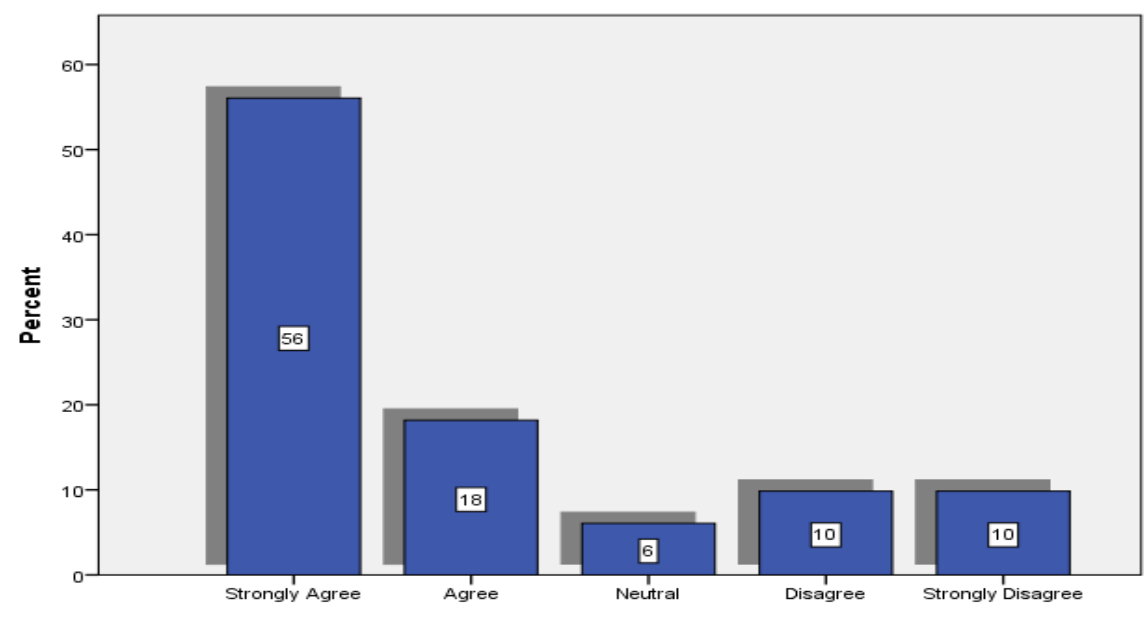

Figure4.5: Insufficient campaign finances

Source: (Field data, 2019)

\subsection{Inclusion of Clan Representatives in the Negotiations}

As Figure 4.6 shows, $36 \%$ of the study participants strongly disagreed that inclusion of each clan's representatives in the negotiations led to their support for consociational democracy while $27 \%$ of the respondents simply disagreed with this statement. Only $4 \%$ of the respondents expressed neutrality with regard to this statement while $14 \%$ agreed that inclusion of each clan's representatives influenced their decision to support. The remaining $20 \%$ of the respondents strongly agreed with the question statement. Thus cumulatively, $63 \%$ of the respondents downplayed the significance of clan representation in the negotiations as a push factor for adoption of consociational negotiated democracy in the management of ethno-political conflicts in Mandera County.

The findings were unexpected as the assumption was that inclusion at the decision making table would be received positively by all clans as a sign of recognition, a key aspect in the pursuit of power. The findings appear to point to the possibility of exclusion of certain clans in the community's political architecture. They may also be suggesting that cooperation of clans in the political sphere of the wider Somali community is not something that most of the residents are enthused about; that a culture of survival for the fittest had taken root among the clans. Moreover, the clans' elite may be unwilling or lack the motivation to bridge the clan cleavages. The results could also mean that a clan's representation in the negotiations did not mean much compared to other factors like equity in resource allocation.

This finding may be interpreted to mean that inclusion is varied and not just about the physical presence of group representatives in decision making; provided the decisions are fair, that would be sufficient. Such an interpretation adds clarity to the emphasis Lijphart (2012) gives to the idea of inclusivity as a success factor in consociational democracy as a potential pathway to peaceful coexistence. Stemming from this finding, the study argues that equity in resource sharing could be deemed as a synonym for inclusivity. The study thus agrees with Cederman, Wimmera and Min (2010) that ethnic groups rebel and initiate conflicts when they are excluded from power and the resources accruing from being in power. 


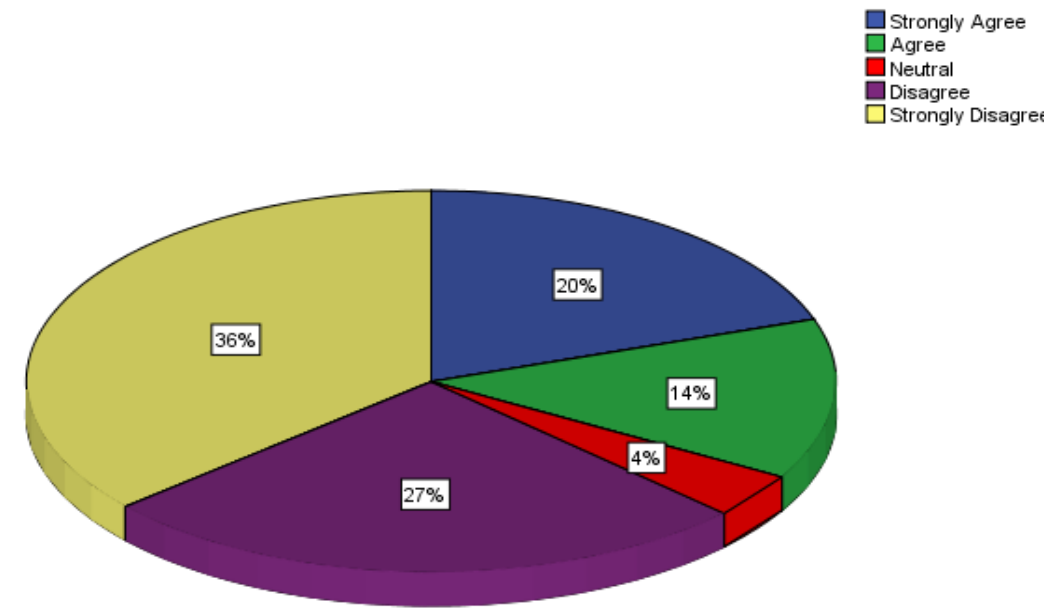

Figure4.6: Inclusion of clan representatives in the negotiations

Source: Field data, 2019

\subsection{The Only Realistic Pathway to an Elective Political Office for Small Clans}

Figure 4.7 shows that $57 \%$ of the respondents agreed that consociationalism was the only realistic path for small clans to hold any county or national elective political office and thus avert ethnically motivated political conflicts. However, $32 \%$ of the respondents did not concur with the statement. The rest, $11 \%$ expressed indifference in their response to this statement.

The study findings suggest that small clans had no chance of ascending to political office outside the consociational democracy model. The finding could as well mean that the bigger clans have monopolized the county political leadership and it would take a different approach to politics other than majoritarianism for smaller clans to get a chance at exercising political power. The study findings may also signify that collusion between the numerically significant clans can perpetually deny the smaller clans political power. Such an eventuality would then mean endless struggles and instability as the small clans seek to show their strength by resorting to violence.

The struggle by groups, big or small, to access and maintain political power is the clearest indication yet that no group wants to perpetually and voluntarily have its fate determined by another. Acquisition of political power presupposes access to all resources, including the instruments or means by which to maintain that power, be they consensual or non-consensual. The study concurs with Cheeseman (2011) that in the absence of elite cohesion to initiate cooperation to share power between them - and by extension the constituencies they represent, perceptions of victimhood increase among smaller groups and this serves to perpetuate instability as they are inclined to adopt violence as their modus operandi. Thus consociationalism as a pathway out of ethnic-based political violence would work for all groups, provided elite decisions and patterns of cooperation are properly configured.
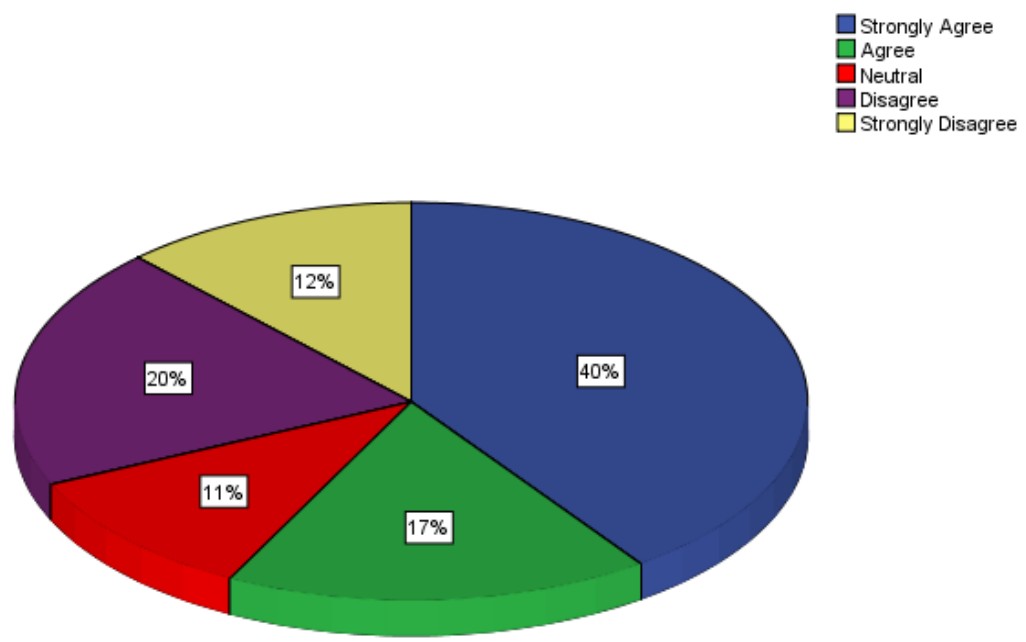

Figure4.7: The only avenue for small clans to hold political office

Source: Field data, 2019 


\subsection{Other Reasons that Influence Adoption of Consociational Negotiated Democracy}

In this question, the researcher wanted to find out whether there were other reasons other than those explored above that motivated the communities living in Mandera County to consider consociational democracy as a useful strategy in managing ethno-political conflicts. A thematic analysis of the responses highlights the unity of the larger Somali community as a key driver towards consociationalism, their clan differences notwithstanding. In this case, the concept of ethnicity takes an instrumental approach. Moreover, that the practice is advocated for by elders renders it worthy of consideration given the immense respect that they command from the community as guardians of the common good. A female respondent from among the key informants corroborated this perspective in an interview on $16^{\text {th }}$ April 2019:

One of the undeniable facts is that we are Somalis first before our membership to our
different clans. A non-Somali and indeed many Somalis cannot pinpoint the difference
between a Garre and a Degodia or Murulle. Thus the unity and preservation of our
culture as Somalis supersedes that of individual clans. Such an agenda driven by the
elders whom we respect as the custodians of our culture and public good will to a very
large extend tend to get support from the community members.

This view by the interviewee was also corroborated by a female member of a Focus Group Discussion (FGD) held in Mandera Town on $18^{\text {th }}$ April 2019 who said that:
The Somali community is one and the institution of elders is highly respected because since time immemorial, it is them that have been making most of the decisions involving conflict resolution which have in many times ended or at least ushered a hiatus in inter- clan rivalries.

An analysis of the above finding indicates the importance of cultural institutions such as the institution of the council of elders in decision making and the value attached to unity and amity among the Somali clans. The practice of cross-clan marriages had brought families together and from such unions, offspring who cannot claim purity in terms of clan identification. However, these ties and the desire for unity and amity, though in sync with the consociational argument that cooperation breeds stability (Lijphart, 2012) does not seem to be the reality in Mandera County given the recurrence of violent conflicts grounded in politics. This study argues that the high political stakes among the clans participating in the electoral processes breed hostilities and accentuate clan differences and consequently violence to the detriment of consociationalism. The respondents appear to point out to the convenience with which the primordial and instrumental identities are used to achieve certain goals; when it is political power contestation at the subnational level, primordialism reigns supreme and when it comes to the national level, the instrumentalist approach seems to have better returns, hence its usage.

The study also established that there exists the fear of self-annihilation among the Somali clans. This finding was intertwined with the more generic cliché: 'the Somali comes ahead of the Murulle, Degodia or Garre'. This finding was succinctly elaborated by a Garre elder in an interview carried out on $24^{\text {th }}$ April 2019, who argued thus:

The community members by virtue of lineage share certain attributes that make them identify with each other by default. Imagine members from related families fighting over things they can discuss and resolve? If the fighting continues for long, the community will no longer exist. So it is up to the leaders of the community to help their kin find alternative ways of settling disagreements.

The fear of self-annihilation of homogenous yet heterogeneous populations is grounded on the fact that by continuously fighting, the primordial groups (clans and sub-clans) will self-destruct and eventually destroy the foundation upon which the instrumental Somali identity is build. In spite of the cleavages at the clan and sub-clans, the Somali identity is aggregate of them all and gives an identity at the national level when pursuing their interests. It is the contention of this study that the reality of self-annihilation at the inter-group lower levels of identification favors a more moderate behaviour among sub-groups rather than a hardline one when it comes to negotiations. To the extent that the Somali language flows across constituent clans, the Islamic religion dominant in all clans, it would 
follow that the constituent clans will tend to cooperate and support consociational democracy because after all the clans are just but members of an extended family.

The study further established that the adoption of consociational democracy in the management of ethno-political conflicts in Mandera County was encouraged by the National Cohesion and Integration Commission (NCIC), in exercise of its mandate to promote alternative dispute resolution mechanisms that thaw inter-ethnic relations. There were also responses indicative of the need to comply with the provisions of Article 174 (d) and (e) which emphasize the right of communities to manage their own affairs and the protection and promotion of the rights and interests of minorities and marginalized communities. Inclusion of all interested parties in the political matrix as contemplated by the supreme law was thus perceived as only possible through the consociational democracy approach. On compliance with the law, a respondent noted thus:

\section{The communities living in Mandera County are first and foremost citizens of Kenya before being members of the Somali community and the respective clans they identify with. Thus, any action undertaken by or in the name of the community must be in conformity with the provisions of the law, precisely the NCIC Act 2008 and Article 174 of the Constitution of Kenya.}

The role of the NCIC was found to have been particularly instrumental in supporting the elders from across the clans reach out and find a workable solution that promotes the rights and interests of all clans in order to enhance peace and stability. It however emerged that the negotiations, were not inclusive in terms of clan representation. The study thus takes the view that exclusion of significant segments undermined the roll out of consociational democracy in the manner contemplated by the legal framework cited above and the proponents of the model. It is therefore no wonder that the 2017 electoral cycle saw stiff opposition to consociational democracy compared to the 2013 electoral cycle.

From the above responses and discussion, it is evident that the Somali community has deep respect for the institution of the elders and it believes that decisions made by the elders are usually in the best interests of the community. The pursuit of unity and fear of communal self-annihilation was a significant factor in favour of adoption of consociational democracy. This explains why some of the active political actors agreed with the elders to step down even when that meant that their political careers would come to an end. Moreover, there is an appreciation of the effort of national institutions such as the NCIC working in concert with traditional institutions in entrenching consociationalism in the promotion of peaceful ethnic relations.

\section{CONCLUSION}

Consociationalism was supported in Mandera County at the inception of devolution in 2013 because of its promise of peace and stability which the community desired. In addition, consociationalism which is pro-equity was deemed the antidote to the pre-existing majoritarian system which was zerosum and the consequence thereof violence.However, over one third of the respondents were cynical that this variant of democracy would deliver fairness, perhaps owing to lessons learnt at the national level where political promises are rarely kept in the post-election phase. The teachings of the dominant Islamic faith on peaceful dispute resolution strongly influenced the adoption of consociational democracy as well as the cross-cutting inter-clan family ties. The study established that despite the inter-clan rivalries, families made up of spouses from different clans were not affected, an indicator as to the high regard and protection for the institution of the family. The study further established that politics being a game of numbers, realpolitik demands that opportunities for wielding power as promised by consociationalism could not be turned down especially by the small clans which benefitted out of the political economies of scale. The design of consociationalism was seen as cost effective because agreements during negotiations if upheld would imply decreased expenditure in campaigns, thus ushering a break from the finance-intensive majoritarian system. The fear of selfannihilation and the desire for communal unity were also found to have predisposed residents of Mandera County towards consociational democracy given that violence threatened not just clan members but the larger Somali community. The high regard in which elders' advice is held in the Somali community and encouragement from state institutions such as the NCIC also played a role in convincing most of the residents of Mandera County that Consociationalism was a game changer in combating politically motivated inter-clan conflicts. It is therefore in the interest of the community as 
the primary actors in Mandera County politics and the state machinery to support consociationalism as a pathway to peace and stability in heterogeneous societies given the manner in which boundaries of political units have been drawn.

\section{REFERENCES}

[1] Abu-Nimer, M. (2010). An Islamic Model of Conflict Resolution: Principles and Challenges in Qamar ulHuda (Ed.)Crescent and Dove: Peace and Conflict Resolution in Islam (pp. 73-87). Washington, D.C.: United States Institute of Peace Press.

[2] Alesina A, Easterly W, Matuszeski J. (2011). Artificial States. Journal of the European Economic Association Vol. 9(2): 246-277

[3] Andeweg, R. (2000). Consociational Democracy Annual Review of Political Science Vol.3: pp.509-36

[4] Ayezaluno, J. (2011). Ghanaian Elections and Conflict Management: Interrogating the Absolute Majority Electoral System. Journal of African Elections Vol.10 (2): pp. 22-53

[5] Binningsbø, H.M. (2005). Consociational Democracy and Post-conflict Peace. Will Power-Sharing Institutions Increase the Probability of Lasting Peace after Civil War? Paper presented at the Annual Norwegian National Political Science Conference, Hurdalsjøen, Norway, 5-7 January

[6] Boone C. (2003). Political Topographies of the African State: Territorial Authority and Institutional Choice. Cambridge: Cambridge University Press

[7] Bratton, M. and Kimenyi, M, S., (2008).Voting in Kenya: Putting Ethnicity in Perspective. Economics Working Papers, Working Paper 2008-09, pp.1-22.

[8] Burnley, C (2011). Natural Resources Conflict in the Democratic Republic of the Congo: A Question of Governance?Sustainable Development Law \& Policy 12, No.: 7-11, 52-53.

[9] Burns, N.\& Grove, S.K.(2003)The practice of nursing research: Conduct, critique and utilization. Toronto: WB Saunders.

[10] Butale, C., (2015). Ethnic Politics as a cause of Ethnic Inequalities in Africa. Retrieved on $6^{\text {th }}$ September 2018 from https://www.iapss.org/wp/2015/11/29/ethnic-politics-as-a-cause-of-ethnic-inequalities-inafrica/

[11] Cammett, M. and Malesky, E. (2012). Power Sharing in Postconflict Societies: Implications for Peace and Governance. Journal of Conflict Resolution Vol. 56, No.6, pp 982-1016.

[12] Cederman, L.E, Wimmer A. \& Min, B. (2010) Why Do Ethnic Groups Rebel? New Data and AnalysisWorld Politics, Volume 62, Issue 1, pp. 87-119

[13] Cheeseman, N. (2015), Democracy in Africa: Successes, failures, and the struggle for political reform, Cambridge: Cambridge University Press.

[14] Cheeseman, N. (2011). The Internal Dynamics of Power-Sharing in Africa Democratization, 18 (2); 336-365.

[15] Cheeseman, N. \& Ford, R., (2007) Ethnicity as a political cleavage Afrobarometer, Working Paper No. 83

[16] CIPEV (2008) Final Report of the Commission of Inquiry into the Post-Election Violence in Kenya available at http://www.knchr.org/Portals/0/Reports/Waki_Report.pdf

[17] Creswell, J.W. (2014). Research Design: Qualitative, Quantitative and Mixed Methods Approaches ( $4^{\text {th }}$ Ed.). Thousand Oaks, CA: Sage.

[18] Creswell, J.W. (2008). Educational Research: Planning, Conducting and Evaluating Quantitative and Qualitative Research, New Jersey: Pearson Education Inc.

[19] Henry, J. (2016). Consociationalism and Identity in Ethnically Divided Societies: Northern Ireland and Malaysia. Studies in Ethnicity and Nationalism 16(3):401-415

[20] Horowitz, D. (2002). Constitutional design: Proposals versus process. In A. Reynolds (Ed.), The architecture of democracy: Constitutional design, conflict management, and democracy (pp. 15-36). Oxford, UK: Oxford University Press.

[21] Kadayifci-Orellana, S.A.\&Sharifa-Funk, M. (2010) Muslim Women Peacemakers As Agents of Change inQamar ul-Huda (Ed.)Crescent and Dove: Peace and Conflict Resolution in Islam(pp. 179198).Washington, D.C.: United States Institute ofPeace.

[22] Kenya, Republic of (2010) Constitution of Kenya Nairobi: Government Printer

[23] Kenya, Republic of (2008) The National Cohesion and Integration Act, Nairobi: Government Printer

[24] Lijphart, Arend. (2012).Patterns of Democracy: Government Forms and Performance in Thirty-Six Countries. London, Yale University press

[25] Murdock GP. (1959) Africa: Its Peoples and Their Culture History. New York: McGraw-Hill Book Company 
[26] Ngoy-Kangoy, H K (2007). The Political Role of the Ethnic Factor around Elections in the Democratic Republic of the Congo African Journal on Conflict Resolution Vol 2: 43-56

[27] Njoroge, E. W. \& Sperling, D., (2017). Addressing ethnic based politics in Kenya: a socio-legal perspective available at https://su-plus.strathmore.edu/handle/11071/5218

[28] Posada-Carbo, E. (2008).Democracy, Parties and Political Finance in Latin America. The Hellen Kellogg Institute for International Studies, Working Paper \#346-April, 2008

[29] Posner, D.N. (2007). Regime Change and Ethnic Cleavages in AfricaComparative Political Studies 40(11):1302-1327

[30] Putnam, R.D. (2000).Bowling Alone: the collapse and revival of American communityNew York: Simon \& Schuster.

[31] Putnam, R.D.(1995) Bowling Alone: America's Declining Social Capital. Journal of Democracy6 (1):6578.

[32] Shamsuddin, K.A, Liaw, J.O.H \&Ridzuan, A.A, (2015) Malaysia: Ethnic Issues and National Security International Journal of Humanities and Social Science Vol. 5, No. 9(1): 136-143

[33] Söderberg, K.M. \&Bjarnesen, J. (2018) Violence in African elections: between democracy and Big Man politics, Uppsala: Zed Books

[34] Tadesse, B.(2010) Women in conflict and indigenous conflict resolution among the Issa and Gurgura clans of Somali in Eastern Ethiopia. African Centre for the Constructive Resolution of Disputes

[35] Teshome-Bahiru, W. (2008). Ethnicity and Political Parties in Africa: The Case of Ethnic-Based Parties in Ethiopia. Journal of International Social Research, 1(5), pp.780-809

[36] Tonah, S. (2007).Introduction: Theoretical and Comparative Perspectives on Ethnicity, Conflicts and Consensus in Ghana in S. Tonah (Ed). Ethnicity, Conflicts, and Consensus in Ghana. Accra: Woeli Publishing Services

[37] Van Dyke, N.\&Amos, B. (2017) Social Movement Coalitions: Formation, Longevity, and Success. Sociology Compass 11:1-17

[38] Vasilev, G. (2015). The Uneasy Alliance between Consensus and Democracy.Review of Politics, Vol. 77(1), pp. 73-98

[39] White, R. W. (2010). Structural Identity Theory and the Post-Recruitment Activism of Irish Republicans: Persistence, Disengagement, Splits, and Dissidents in Social Movement Organizations. Social Problems 57(3): 341-370.

[40] Woolcock, M. (1998)Social capital and economic development: Toward a theoretical synthesis and policy frameworkTheory and Society27: 151-208

Citation: Joseph M. Mutungi. "Push Factors towards Consociational Democracy in Plural Sub-National Polities: The Case of Mandera County, Kenya". International Journal of Humanities Social Sciences and Education (IJHSSE), vol. 6, no.10, 2019, pp. 12-25. doi: http://dx.doi.org/10.20431/2349-0381.0610002.

Copyright: (C) 2019 Authors. This is an open-access article distributed under the terms of the Creative Commons Attribution License, which permits unrestricted use, distribution, and reproduction in any medium, provided the original author and source are credited. 